\title{
KOMUNIKASI ORGANISASI TATA KELOLA ANGGARAN DAERAH (Studi Kasus Festival Anggaran III-2017 Pada Pemerintah Kabupaten Batang, Jawa Tengah)
}

\author{
Rachmi Kurnia Siregar, Wenny Maya Arlena \\ Program Studi Ilmu Komunikasi, Fakultas Ilmu Komunikasi, \\ Universitas Budi Luhur \\ rachmi.kurnia@budiluhur.ac.id, wenny.maya@budiluhur.ac.id
}

\begin{abstract}
Post-Reform Corruption, Collusion and Nepotism (KKN) practices involving executives, judiciary and legislatures continue to increase, as the State Budget $(A P B N)$ and the Regional Budget (APBD) sped up. One of the causes is the weakness of transparency of budget management. The regency government of Batang, Central Java in the era of Yoyok Riyo Sudibyo Regent (2012-2017) seeks to create local budget transparency by holding Budget Festival (FA) containing accountability report of $A P B D$ and development program of previous year. In addition to implementing e-Government, auctioning offices and establishing Public Service Quality Improvement Unit (UPKP2). This study uses qualitative methods, case studies and triangulation of data with the aim of: 1) Analyzing the communication policy process and communication policy making process FA 2) Assessing obstacles in the implementation of FA policy. Result of research: following the change of leadership, Regent of Batang period 2017-2022, Wihaji remove in the administration of the governance. However, Wihaji remains committed to implement transparent, accountable and participatory governance by strengthening e-Government and Smart City. Pemkab Batang is advised to continue the transparency program of APBD governance through the Budget Festival in accordance with the current condition. This gait is important to maintain a strong social interaction between bureaucrats and people in the digital age. As well as the identity and characteristics of the region in supporting the development of identity-based flagship areas to improve the competitiveness (city branding).
\end{abstract}

Keyword: communication policy, communication in organization, transparency, budget festival.

\begin{abstract}
ABSTRAK
Praktik Korupsi, Kolusi dan Nepotisme (KKN) pasca Reformasi melibatkan eksekutif, yudikatif dan legislatif terus meningkat, seiring melesatnya Anggaran Pendapatan Belanja Negara (APBN) maupun Anggaran Pendapatan Belanja
\end{abstract}


Daerah (APBD). Salah satu penyebabnya yakni lemahnya transparansi tata kelola anggaran. Pemerintah Kabupaten (Pemkab) Batang, Jawa Tengah di era Bupati Yoyok Riyo Sudibyo (2012-2017) berupaya menciptakan transparansi anggaran daerah dengan menyelenggarakan Festival Anggaran (FA) berisi laporan pertanggungjawaban APBD dan program pembangunan tahun sebelumnya. Selain menerapkan e-Government, lelang jabatan dan membentuk Unit Peningkatan Kualitas Pelayanan Publik (UPKP2). Penelitian ini menggunakan metode kualitatif, studi kasus dan triangulasi data dengan tujuan: 1) Menganalisis proses kebijakan komunikasi dan proses pembuatan kebijakan komunikasi FA 2) Mengkaji kendala penerapan kebijakan FA. Hasil penelitian: seiring pergantian kepemimpinan, Bupati Batang periode 2017-2022, Wihaji mencoret FA dalam penyelenggaraan pemerintahan. Namun Wihaji tetap berkomitmen menjalankan tata kelola pemerintahan yang transparan, akuntabel dan partisipatif di antaranya dengan memperkuat e-Government dan Smart City. Pemkab Batang disarankan melanjutkan program transparansi tata kelola APBD melalui Festival Anggaran disesuaikan dengan kondisi terkini. Kiprah ini penting untuk tetap menjalin interaksi sosial yang kokoh antara birokrat dengan masyarakat di era digital. Serta sebagai identitas maupun karakteristik kawasan dalam mendukung pembangunan kawasan unggulan berbasis identitas untuk meningkatkan daya saing (city branding).

Kata kunci: Kebijakan Komunikasi, Komunikasi dalam Organisasi, Transparansi, Festival Anggaran.

\section{PENDAHULUAN}

\begin{tabular}{|c|}
\hline $\begin{array}{rcr}\text { Pasca } & \text { Reformasi } & \text { seiring } \\
\text { melesatnya } & \text { APBN maupun }\end{array}$ \\
\hline $\begin{array}{l}\text { APBD, kasus korupsi yang } \\
\text { melibatkan eksekutif, legislatif } \\
\text { dan yudikatif menjamur. Selama } \\
\text { 2010-2014, aparat menyidik } 2.492\end{array}$ \\
\hline $\begin{array}{l}\text { kasus korupsi dengan nilai } \\
\text { kerugian negara Rp } 30 \text { triliun dan }\end{array}$ \\
\hline nilai suap $R p$ \\
\hline $\begin{array}{llr}\text { Tingginya } & \text { kasus korupsi salah } \\
\text { satunya } & \text { karena } & \text { pengelolaan } \\
\text { negara maupun pemerintahan }\end{array}$ \\
\hline
\end{tabular}

Padahal transparansi sangat penting demi terwujudnya tata pemerintahan yang baik (good public governance) terkait penyelenggaraan pemerintahan yang "bersih", demokratis dan efektif. Upaya ini hanya dapat dilakukan jika terjadi keseimbangan peran ketiga pilar yaitu pemerintah, dunia usaha swasta dan masyarakat. Mengantisipasi korupsi, kolusi dan nepotisme (KKN) dijajarannya, Bupati Batang 
Yoyok Riyo Sudibyo yang mulai bertugas pada 2012 membangun kepercayaan publik. Ini dilakukan karena mantan bupati sebelumnya terjerat kasus korupsi APBD. Berbagai terobosan dilancarkan mulai menerapkan lelang jabatan membentuk Unit Peningkatan Kualitas Pelayanan Publik (UPKP2), layanan pengadaan secara elektronik serta mengadakan Festival Anggaran, (untuk selanjutnya disingkat FA), yang merupakan pertanggungjawaban penggunaan APBD tahun sebelumnya.

Semula FA dilakukan dengan membagikan brosur, pamflet dan rapat akbar tapi hal ini dinilai tidak efektif. Mulai 2014, FA diselenggarakan secara indoor di samping rumah dinas Bupati Batang yang menampilkan anggaran SKPD dan kelurahan dari masing-masing kecamatan dalam bentuk booth.

Kiprah Bupati Batang ini meraih penghargaan Bung Hatta Anti Corruption Award 2015 bersama Walikota Surabaya, Tri Rismaharini. Pemkab Batang yang mengklaim sebagai pelopor FA di Indonesia kini menjadi pusat pembelajaran bagi pemerintahan lainnya mulai tingkat kabupaten, kota hingga provinsi. Pemkab Karang Anyar mengadopsi FA Batang 2016 namun memamerkan anggaran tahun berjalan.

Upaya Yoyok menggelar FA bertujuan memenuhi UU No 14 tahun 2008 tentang Keterbukaan Informasi Publik (KIP) yang diberlakukan 1 Mei 2010. Melalui UU tersebut, diharapkan dapat mendorong transparansi dalam pengelolaan negara serta meningkatkan partisipasi masyarakat. Bahkan dengan penerapan UU ini, setiap badan publik harus mempersiapkan diri secara optimal, karena informasi yang bersifat rahasia sekalipun dapat dibuka oleh Komisi Informasi untuk umum dalam merespon permohonan pemohon informasi publik.

Situs Blitar.go.id mengemukakan keterbukaan informasi publik berupaya memberi pemahaman kepada masyarakat terkait rencana pembuatan kebijakan, program kebijakan publik dan proses pengambilan keputusan publik serta alasan pengambilan suatu 
keputusan publik.

Berdasarkan identifikasi masalah dan batasan masalah, maka perumusan masalah dalam penelitian ini sebagai berikut:

a. Bagaimana kebijakan

komunikasi dan pembuatan keputusan kebijakan

komunikasi FA?

b. Apa kendala yang dihadapi

Pemkab Batang dalam menerapkan kebijakan FA?

Adapun penelitian ini bertujuan sebagai berikut:

a. Menganalisis kebijakan

komunikasi dan pembuatan keputusan kebijakan komunikasi FA.

b. Mengkaji kendala yang dihadapi Pemkab Batang dalam menerapkan kebijakan FA.

\section{KERANGKA PEMIKIRAN}

Komunikasi Organisasi

Conrad (dalam Tubbs dan Moss,2005) mengidentifikasi tiga fungsi komunikasi organisasi yaitu:

1. Fungsi perintah berkenaan dengan anggota-anggota organisasi mempunyai hak dan kewajiban membicarakan, menerma, menafsirkan dan bertindak atas suatu perintah. Tujuan dari fungsi perintah adalah koordinasi antara sejumlah anggota yang bergantung dalam organisasi tersebut.

2. Fungsi relasional terkait dengan komunikasi memperbolehkan anggotaanggota menciptakan dan mempertahankan hubungan personal dengan anggota organisasi lain.

3. Fungsi manajemen ambigu terkait pilihan dalam situasi organisasi kerap dibuat dalam keadaan yang sangat ambigu. Komunikasi adalah alat untuk mengatasi dan mengurangi ketidakjelasan yang melekat dalam organisasi.

Dikaitkan dengan fungsi komunikasi dalam organisasi, peneliti membatasi untuk mengkaji fungsi perintah yakni pada prinsipnya individu dalam organisasi memiliki hak dan kewajiban untuk membicarakan, menerima, menafsirkan dan bertindak atas suatu perintah. 


\section{Struktur Organisasi}

Adanya pola interaksi

dalam suatu organisasi juga

diperkuat oleh Robbins (2003) di

mana struktur organisasi

mengatur dan mengelompokkan

pembagian tugas yang

dikoordinasikan secara formal. Ia

mengelompokkan 6 unsur dalam

merancang struktur organisasi

sebagai berikut:

1. Spesialisasi pekerjaan, pada tingkat apa tugas dibagikan dalam pemisahan pekerjaan.

2. Departementalisasi, di mana pengelompokkan pekerjaan dilakukan atas dasar tugas yang sama atau mirip sehingga pekerjaan tersebut dapat dikoordinasikan.

3. Rantai komando, untuk siapa laporan yang dibuat individu dan kelompok.

4. Rentang kendali, berapa banyak individu yang dapat diatur.

5. Sentralisasi dan desentralisasi, di mana letak wewenang pengambilan keputusan.

6. Formalisasi, pada tingkat apa suatu aturan dan kemudahannya akan mengatur pekerjaan dari

manager.

Bertolak dari struktur organisasi di atas, peneliti membatasi mengkaji rantai komando yakni untuk siapa laporan yang dibuat individu dan kelompok.

\section{Dimensi Komunikasi dalam}

\section{Organisasi}

Dalam kehidupan organisasi (Romli,2014:6) terdapat dua dimensi komunikasi yakni:

1. Komunikasi internal organisasi adalah proses penyampaian pesan antara anggota-anggota organisasi yang terjadi untuk kepentingan organisasi, seperti komunikasi antara pimpinan dan bawahan, antara sesama bawahan,dan sebagainya. Komunikasi internal lazim dibedakan menjadi dua bagian:

a. Komunikasi vertikal yaitu komunikasi dari atas ke bawah dan dari bawah ke atas. Komunikasi dari pimpinan kepada bawahan dan dari bawahan ke pimpinan. 


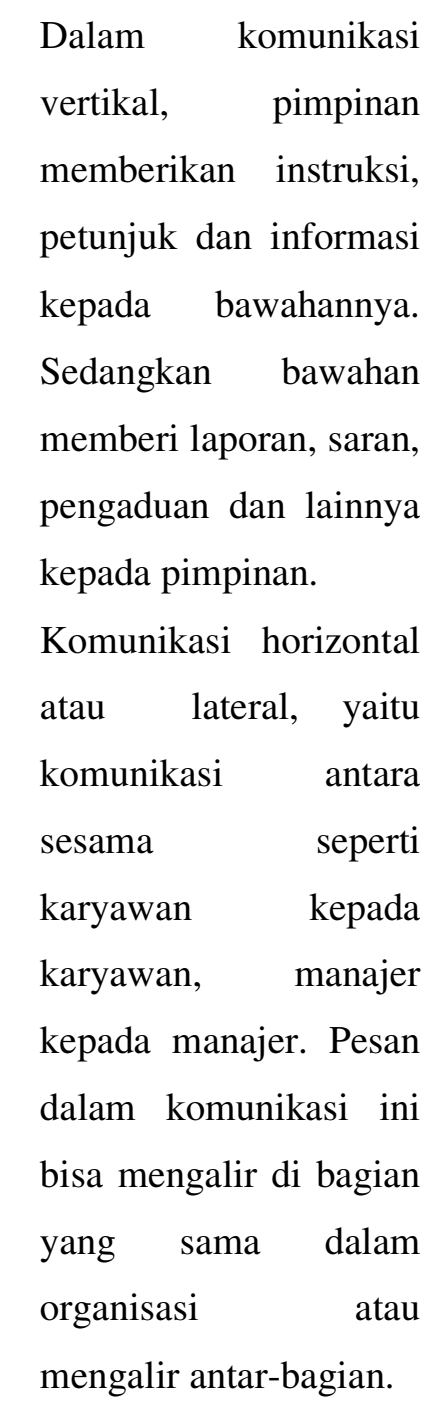

2. Komunikasi eksternal organisasi ialah komunikasi antara pimpinan organisasi dengan khalayak di luar organisasi. Pada organisasi besar, komunikasi ini lebih banyak dilakukan oleh kepala hubungan masyarakat daripada pimpinan kecuali hal yang penting.
a. Komunikasi
dari organisasi kepada

khalayak dapat melalui berbagai bentuk seperti majalah organisasi, press release, artikel surat kabar.

b. Komunikasi dari khalayak kepada organisasi berupa umpan balik dari kegiatan yang dilakukan organisasi.

Peneliti membatasi untuk mengkaji komunikasi dalam organisasi pada dimensi komunikasi internal yang difokuskan pada komunikasi vertikal.

\section{Teori Informasi Organisasi}

Teori Informasi Organisasi di bawah naungan pemikiran Sibernatika, digagas Karl Weick dalam Little John (2011:364) memandang susunan sebagai sesuatu yang muncul dari polapola interaksi dalam organisasi. Teori ini mengkombinasikan siklus perilaku komunikasi dan aturan bersama sebagai strategi organisasi untuk meminimalisir ketidakpastian informasi.

Dalam siklus perilaku komunikasi meliputi:

1. Aksi/tindakan yang 
merupakan suatu pernyataan atau perilaku seorang individu. Suatu aksi mengacu pada pernyataan komunikasi dan perilaku yang menunjukkan ketidakpastian seseorang.

2. Interaksi/repons yaitu reaksi terhadap aksi. Suatu respon bertujuan mengklarifikasi terhadap informasi yang tidak pasti dan dikemukakan sebagai hasil dari aksi yang dilakukan sebelumnya.

3. Penyesuaian yaitu tanggapan terhadap respon yang merupakan penyesuaian terhadap aksi yang diterima sebelumnya.

4. Interaksi ganda yaitu siklus dari aksi, respon dan penyesuaian dalam berbagai pertukaran informasi. Interaksi ganda mengacu pada sejumlah siklus perilaku komunikasi yang digunakan untuk membantu anggota organisasi dalam mengurangi ketidakpastian informasi. Contoh interaksi ganda misalnya rapat rutin, konferensi, menelepon, saling mengirim memo, diskusi, interview dan sebagainya.
Sedangkan dalam aturan bersama, Weick menekankan pengaturan terhadap aktivitas anggota organisasi.

Bertolak dari penjelasan di atas, peneliti membatasi mengkaji bagaimana siklus perilaku komunikasi organisasi yang berlangsung di Pemkab Batang khususnya dikaitkan dengan Festival Anggaran sebagai subjek penelitian ini.

\section{Kebijakan Komunikasi}

Kebijakan komunikasi berkaitan dengan perkembangan sosial, politik dan ekonomi sebuah negara. Chakravartty dan Sarikakis $(2006,7)$ dalam Abrar (2008:4) mengungkapkan kebijakan komunikasi memiliki konteks, domain dan paradigma. Kebijakan komunikasi memiliki lima kriteria: 1) Memiliki tujuan tertentu 2) Berisi tindakan pejabat pemerintah 3) Memperlihatkan tindakan yang dilakukan pemerintah 4) Bisa bersifat positif atau negatif 5) Bersifat memaksa (otoritatif). Tujuan kebijakan komunikasi dari sisi sosiologi adalah menempatkan proses komunikasi sebagai bagian dari dinamika sosial yang tidak 
merugikan masyarakat. Kebijakan komunikasi pada intinya bertujuan mendukung kelancaran sistem komunikasi yang berlaku dalam suatu negara (Abrar:2008:16-17)

Dari pengertian di atas, penulis memahami kebijakan publik adalah tindakan yang dilakukan pemerintah ataupun yang tidak dilakukan pemerintah sehubungan dengan tujuan yang hendak dicapai sehingga dapat memengaruhi tindakan individu dalam masyarakat.

Dalam upaya mengimplementasikan kebijakan publik, sepatutnya dibuat sejumlah tahapan sebagai prosedur kerja agar sasaran dan target dapat tercapai. Dunn (2003:24-25) menguraikan proses pembuatan kebijakan publik dituangkan dalam lima tahapan yang saling bergantung diatur menurut urutan waktu sebagai berikut:

1. Penyusunan agenda; pada tahap ini pejabat yang dipilih dan diangkat menempatkan masalah pada agenda publik.

2. Formulasi kebijakan; para pejabat merumuskan alternatif kebijakan untuk mengatasi masalah dan memandang perlunya dibuat perintah eksekutif, keputusan peradian, dan tindakan legislatif.

3. Adopsi kebijakan; alternatif kebijakan yang diadopsi dengan dukungan dari mayoritas legislatif, konsensus di antara lembaga direktur lembaga atau keputusan peradilan.

4. Implementasi kebijakan: kebijakan yang telah diambil dilaksanakan setelah oleh unit-unit administrasi yang memobilisasikan sumberdaya finansial dan manusia.

5. Evaluasi kebijakan; unit-unit pemeriksaan dan akutansi dalam pemerintahan menentukan apakah badanbadan eksekutif, legislatif dan peradilan memenuhi undangundang dalam pembuatan kebijakan dan pencapaian tujuan.

\section{Transparansi}

Transparansi merupakan salah satu syarat penting untuk menciptakan good governance. Dengan adanya transparansi di setiap kebijakan dan keputusan dilingkungan organisasi dan 
pemerintahan, keadilan dapat ditumbuhkan. (Tahir,2014:109).

Makna dari transparansi dalam penyelenggaraan pemerintahan daerah dapat dilihat dari dua hal yaitu:

1. Salah satu wujud pertanggung jawaban pemerintah kepada rakyat

2. Upaya peningkatan manajemen pengelolaan dan penyelenggaraan

pemerintahan yang baik dan meminimalisir peluang praktek kolusi, korupsi dan nepotisme (KKN).

3. Upaya peningkatan manajemen pengelolaan dan penyelenggaraan

pemerintahan yang baik dan meminimalisir peluang praktek kolusi, korupsi dan nepotisme (KKN).

4. Upaya peningkatan manajemen pengelolaan dan penyelenggaraan

pemerintahan yang baik dan meminimalisir peluang praktek kolusi, korupsi dan nepotisme $(\mathrm{KKN})$.

Dalam penelitian ini penulis membatasi transparansi pengelolaan keuangan daerah dari penggunaan

Anggaran
Pendapatan Belanja Daerah (APBD) maupun program pembangunan yang akan dilakukan, sebagai implementasi dalam penyelenggaraan pemerintahan daerah sesuai Undang-Undang (UU) No 28 tahun $1999 \quad$ tentang penyelenggaraan negara yang bersih dan bebas KKN. Serta diberlakukannya UU RI No 14 tahun 2008 tentang Keterbukaan Informasi Publik (KIP).

\section{Festival Anggaran}

\section{Festival}

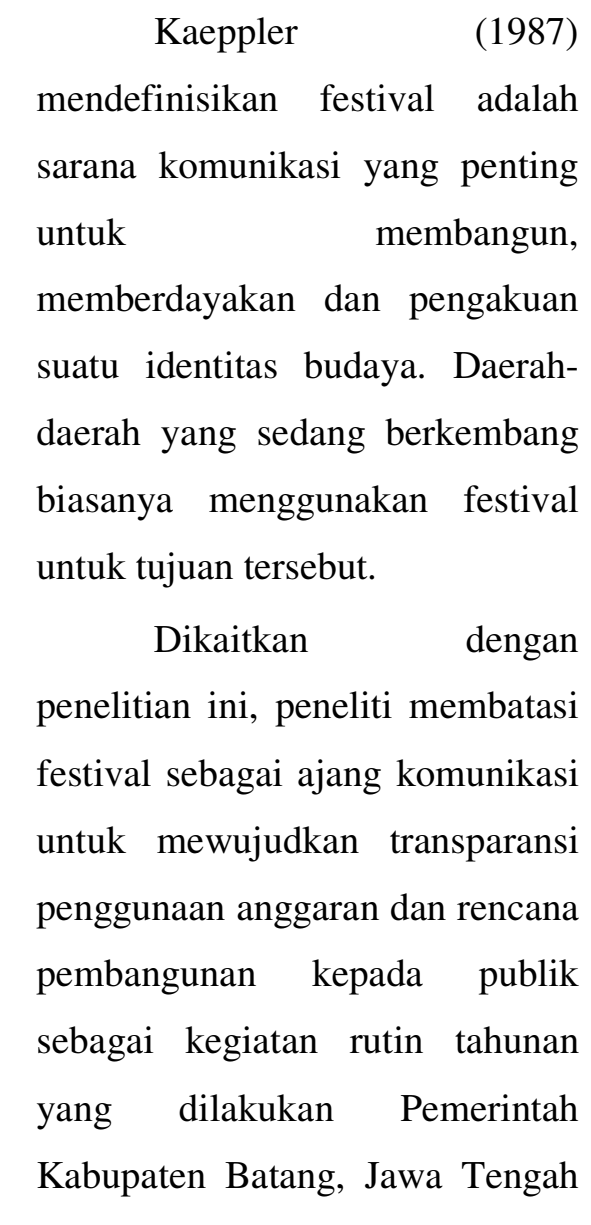


sesuai prinsip demokrasi maupun era keterbukaan informasi.

\section{Anggaran}

Pemerintah melalui

Undang-Undang Nomor 17 tahun

2003 mendefisinikan anggaran sebagai alat akuntabilitas, manajemen dan kebijakan ekonomi. Sebagai instrumen kebijakan ekonomi, anggaran berfungsi untuk mewujudkan pertumbuhan dan stabilitas perekonomian serta pemerataan pendapatan dalam rangka mencapai tujuan bernegara.

Anthony dan Young (2003) dalam Adrianto (2011:7) menguraikan anggaran sebagai suatu rencana yang disajikan secara kuantitatif, biasanya dinyatakan dalam satuan uang yang di susun untuk periode waktu tertentu, biasanya satu tahun. Anggaran secara jelas mengekspresikan apa yang akan dilakukan selama satu tahun kedepan dan menyatakan juga otoritas penggunaan sumber daya keuangan yang diperlukan.

Berdasarkan uraian di atas, maka Festival anggaran adalah ajang komunikasi untuk mewujudkan transparansi penggunaan keuangan daerah maupun rencana kerja yang berlaku untuk periode tertentu dalam bentuk uang, yang disampaikan kepada publik sebagai kegiatan rutin tahunan Pemerintah Kabupaten Batang, Jawa Tengah sesuai prinsip demokrasi maupun era keterbukaan informasi dalam mewujudkan tata kelola pemerintahan yang baik dan bebas Kolusi, Korupsi dan Nepotisme $(\mathrm{KKN})$.

\section{METODE PENELITIAN}

Penelitian

ini menggunakan metode studi kasus dengan pendekatan kualitatif deskriptif menggambarkan suatu variabel, keadaan, fenomena atau gejala sosial tertentu. Pemilihan tempat dalam penelitian ini dilakukan secara purposive yaitu Pemkab Batang, Jawa Tengah yang mengadakan FA sejak 2013.

Peneliti menggunakan metode penelitian studi kasus dengan tipe intrisik dan desain penelitian single case holistic yakni untuk mengungkapkan fenomena atau gejala sosial tertentu dari kebijakan FA sebagai inovasi Bupati Batang (20122017) untuk menerapkan 
transparansi secara langsung, terbuka dan dialogis. Komunikasi organisasi FA tersebut dikaji melalui proses kebijakan komunikasi, proses pembuatan kebijakan komunikasi serta kendala yang dihadapi Pemkab Batang dalam penerapan FA.

Peneliti mewawancarai Bupati dan jajaran Pemkab Batang terkait FA. Serta kalangan DPRD, LSM anti korupsi, tokoh adat, tokoh masyarakat dan pengunjung di FA. Penelitian dilakukan mulai Januari hingga Desember 2017. Selain wawancara, peneliti juga melakukan observasi dan dokumentasi.

Analisis data dilakukan dengan analisis interpretif dan triangulasi data dari hasil pengamatan dan wawancara terhadap subjek penelitian yang telah ditentukan. Analisis interpretif digunakan untuk menetapkan strategi kebijakan komunikasi organisasi melalui FA.

HASIL DAN PEMBAHASAN

\section{Proses Komunikasi dalam}

\section{Organisasi}

Komunikasi adalah sebuah proses, suatu kegiatan yang memiliki banyak kegiatan yang memiliki banyak langkah terpisah tetapi saling berhubungan sepanjang waktu (Ruben, 2014:16). Organisasi sebagai sistem terbuka dan dinamis ditandai oleh masing-masing anggota yang saling menciptakan dan menukar pesan. Penciptaan dan pertukaran pesan itu berlangsung terus menerus (Romli, 2011:13).

$$
\text { Hal ini seperti }
$$
diungkapkan pejabat di jajaran Pemkab Batang saat diwawancara peneliti yakni:

"Proses komunikasi berlangsung lancar-lancar saja. Saat itu pak bupati dalam rapat menyampaikan idenya untuk buka-bukaan tentang penggunaan APBD kepada rakyat selaku pemegang mandat. Hal ini sesuai sumpah beliau saat dilantik pada Februari 2012 yang bertujuan melaporkan langsung hasil kerja terutama pengelolaan anggaran kepada rakyat secara langsung dan terbuka. Hasil rapat, kami diskusikan dengan tim terkait dalam panitia," kata Retno Dwi Irianto, Kabag Organisasi Setda Batang (Sumber: hasil wawancara 
peneliti pada 16 Maret 2016 di Pemkab Batang)

"Proses komunikasi tentang transparansi anggaran melalui festival anggaran di Kabupaten Batang merupakan terobosan karena belum pernah ada pemerintah daerah sebelumnya yang melakukan hal tersebut. Kami tentu saja mendukung ide dan gagasan tersebut penting untuk semakin mewujudkan good government dan mendukung pemberantasan KKN," kata Agus Wimoyo, Kepala Bidang Statistik Pengendalian Evaluasi (Stadalev) Bapeda Pemkab Batang (Sumber: hasil wawancara peneliti pada 16 Maret 2016 di Pemkab Batang)

Dari dua wawancara di atas, menggambarkan proses komunikasi yang dilakukan Bupati Yoyok menyangkut Festival Anggaran berjalan dalam koridor atasan ke bawahan, serta bawahan ke sesama rekan kerja untuk melaksanakan kegiatan tersebut.

Bertolak dari hal tersebut, sejalan dengan pengertian komunikasi sebagai proses oleh individu dalam suatu hubungan, kelompok, organisasi dan masyarakat dengan membuat dan menggunakan informasi untuk berhubungan satu sama lain dengan lingkungan.

\section{Fungsi Komunikasi dalam}

\section{Organisasi}

Fungsi komunikasi dalam organisasi dibatasi pada fungsi perintah yakni Bupati Batang (2012-2017) Yoyok memerintahkan jajarannya untuk menerapkan transparansi sebagai bagian dari prinsip good governance, khususnya informasi pengelolaan keuangan daerah yang diwujudkan dalam FA.

Berikut wawancara dengan Yoyok pada FA 2016 di Pemkab Batang:

"Festival Anggaran merupakan janji dan sumpah saya kepada rakyat selaku pemegang mandat tertinggi dalam kehidupan domokrasi. Festival ini juga sebagai bagian HUT Kabupaten Batang. Setahun setelah dilantik, saya bermaksud melaporkan kinerja saya langsung ke rakyat. Selama ini pertanggungjawaban APBD normatif ke DPRD. Semula menyebarkan brosur dan selebaran berisi laporan penggunaan APBD dan progres pembangunan, tapi hasilnya tak optimal. Selanjutnya saya kumpulkan seluruh camat dan berharap dapat disampaikan ketuk tular kepada warganya masingmasing, tapi tetap saja tak maksimal. Lalu ada ide kenapa tidak difestivalkan saja seperti festival budaya yang lazimnya 
rutin dilakukan setiap tahun. Akhirnya pada 2014 untuk pertama kalinya Festival Anggaran dibuat secara lebih formal di lingkungan kantor agar mudah diakses masyarakat. Teman-teman SKPD saat itu ada yang senang tapi juga sebaliknya. Bahkan ada yang mundur karena tidak siap dengan program yang saya terapkan terutama menyangkut transparansi penggunaan APBD. Melalui Festival Anggaran, saya instruksikan kepada seluruh SKPD, camat, lurah dan kepala desa untuk buka-bukaan penggunaan anggaran agar bisa diketahui langsung oleh rakyat. Diharapkan ada respon dari rakyat, karena sebelumnya saya sudah membuka akses bagi rakyat untuk berpartisipasi sejak awal pembangunan yang diawali melalui rapat Musrenbang dari berbagai jenjang. Mereka diharapkan aktif memberikan usulan, masukan hingga kritik." (Sumber: hasil wawancara peneliti pada 16 Maret 2016 di Pemkab Batang)

Berdasarkan hasil wawancara di atas, perintah yang merupakan gagasan/ide/inovasi Yoyok untuk dilaksanakan jajaran Pemkab Batang seraya berkoordinasi antara masingmasing SKPD, kecamatan, kelurahan hingga desa.

\section{Struktur Organisasi}

Pada FA Batang 2016, Bupati Yoyok mengeluarkan Keputusan No 900/152/2016 tentang pembentukan tim Pameran Transparansi Anggaran (PTA) tahun 2016. Penanggungjawab susunan keanggotaan tersebut yakni Bupati Batang, Wakil Bupati sebagi Wakil Penanggungjawab, Ketua oleh Sekretaris Daerah yang melibatkan jajaran setempat. Tugas pokok tim antara lain mengadakan perencanaan dan persiapan PTA, melaksanakan koordinasi dengan instansi terkait dan pihak lain dalam penyelenggaraan PTA, melaksanakan PTA 2016 dan melaporkan kegiatan kepada Bupati.

\section{Dimensi Komunikasi dalam}

\section{Organisasi}

Dimensi komunikasi

dalam oganisasi yang dikaji adalah komunikasi vertikal dalam komunikasi internal organisasi dikaitkan dengan FA Batang 2016 di era Yoyok Riyo Sudibyo.

Yoyok menginstruksikan bawahannya untuk merealisasikan 


$\begin{array}{lrl}\text { gagasan/ide } & \text { transparansi } & \text { Setda Batang, Retno Dwi Irianto } \\ \text { penggunaan APBD agar bisa } & \text { yang menjabat Plt Asisten Admin } \\ \text { diketahui publik secara utuh, } & \text { Setda Batang mengatakan sebulan } \\ \text { terbuka dan bertanggungjawab. } & \text { sebelum pelaksanaan, mereka } \\ \text { Setelah hasilnya minim pada } & \text { mengadakan rapat panitia yang } \\ \text { tahun pertama dan kedua, FA } & \text { dibentuk bupati untuk PTA. } \\ 2014 \text { dan 2016 diadakan di } & \text { Selain menyampaikan hasil } \\ \text { lingkungan kantor bupati. } & \text { laporan kerja, panitia juga } \\ \text { Berikut petikan } & \text { memberikan saran dan masukan } \\ \text { wawancara dengan Yoyok pada } & \text { ke bupati saatitu. }\end{array}$

FA 2016:

"Festival Anggaran Batang merupakan inovasi pelayanan publik untuk mewujudkan misi transparansi anggaran sesuai amanat UU No 23 tahun 2014 tentang Pemerintahan Daerah dan UU No 25 tahun 2009 tentang Pelayanan Publik. Saya mengumpulkan seluruh jajaran agar inovasi ini bisa berjalan sehingga masyarakat dapat mengetahuinya. Di sisi lain dengan blak-blakan seperti ini diharapkan mampu membangun partisipasi masyarakat dalam pembangunan sehingga dapat pula membangun kepercayaan masyarakat terhadap jalannya pemerintahan. Untuk itu saya memberikan instruksi, informasi dan petunjuk agar transparansi anggaran bisa dilakukan melalui Festival Anggaran yang dibiayai APBD (Ibid, Yoyok Riyo Sudibyo)."

\begin{tabular}{lrr}
\multicolumn{2}{c}{ Sedangkan di } & jajaran \\
bawah menanggapi & instruksi \\
tersebut dengan & melakukan \\
serangkaian $\quad$ rapat & untuk \\
merealisasikannya. & Kabag & Orda
\end{tabular}

\section{Teori Informasi Organisasi}

$$
\text { Weick menekankan }
$$

aktivitas komunikasi dan pentingnya berorganisasi dalam bidang komunikasi, sehingga status dan peranan individu tidak penting. Ini karena komunikasi merupakan dasar pengorganisasian manusia dan dasar pemikiran dalam memahami manusia berorganisasi. Kegiatan berorganisasi berfungsi mengurangi ketidakpastian informasi.

$$
\text { Kajian tersebut peneliti }
$$
lakukan setelah mewawancarai narasumber berkompeten di lingkungan Pemkab Batang sebagai berikut:

1. Aksi; Bupati Batang periode 2012-2017 Yoyok Riyo Sudibyo melontarkan ide kepada bawahannya dalam rapat untuk melaporkan 
langsung kepada masyarakat berupa pertanggungjawaban kerja khususnya penggunaan anggaran. Pelaporan langsung kepada publik ini sesuai sumpahnya kepada masyaraka saat dilantik sebagai Bupati Batang pada Februari 2012 untuk secara transparan akan menginformasikan

transparansi anggaran yang merupakan informasi publik untuk diketahui publik.

2. Interaksi/respons; Setelah Yoyok menyampaikan gagasannya dalam rapat, mayoritas PNS mendukung rencana untuk pameran transparansi anggaran. Sebagian lainnya mengklarifikasi terkait gagasan tersebut antara lain format ataupun implementasinya, kapan, di mana dan lainnya. Namun PNS lainnya ada yang mempertanyakan buka-bukaan anggaran itu apakah hanya untuk mencari sensasi atau pencitraan yang kerap dilakukan pejabat publik. PNS juga mempertanyakan ide tersebut sebagai informasi yang tidak pasti mengingat apakah ide itu bersifat permanen atau hanya di kepemimpinan Yoyok.

3. Penyesuaian; Yoyok menjelaskan baik dukungan maupun klarifikasi terhadap gagasannya untuk bukabukaan anggaran kepada rakyat, harus segera dilakukan sejalan dengan sumpahnya kepada masyarakat saat dilantik. Tepatnya diadakan setahun setelah menjabat sebagai bupati sebagai bentuk pertanggungjawaban langsung kepada rakyat sehingga membangun kepercayaan publik. Selama ini pertanggungjawaban APBD hanya dilakukan secara normatif ke DPRD. Yoyok mengklaim upayanya untuk mendorong keterbukaan informasi publik akan penggunaan anggaran dan program pembangunan, bukan merupakan pencitraan tapi sebagai janjinya saat dilantik sebagai bupati untuk memberantas KKN.

4. Interaksi ganda; untuk memudahkan realisasi gagasan Festival Anggaran, menurut Asisten 1 Setda Batang, Retno Dwi Irianto, Bupati Yoyok menggelar 
rapat rutin, menelepon

bawahannya, mengadakan

forum diskusi, jumpa pers dengan media massa, membuat Surat Keputusan

Bupati untuk pembentukan kepanitiaan event tersebut, hingga rapat evaluasi program pasca Festival Anggaran.

\section{Transparansi}

Transparansi penggunaan APBD melalui FA dimaknai sebagai realisasi langsung pertanggungjawaban Bupati Yoyok kepada rakyat secara terbuka dan dialogis. Serta meningkatan manajemen pengelolaan dan penyelenggaraan pemerintahan sesuai good governance untuk meminimalisir KKN. Dalam event tersebut, jajaran Pemkab Batang sesuai instruksi Yoyok memamerkan laporan penggunaan APBD melalui sejumlah booth di ajang festival sesuai Undang-Undang (UU) No 28 tahun 1999 tentang penyelenggaraan negara yang bersih dan bebas KKN. Serta UU RI No 14 tahun 2008 tentang Keterbukaan Informasi Publik (KIP).

\section{Festival Anggaran}

Pemaparan penggunaan anggaran dan program pembangunan secara transparan di era Bupati Yoyok awalnya dilakukan dengan membagikan selebaran, brosur hingga rapat akbar tapi dinilai tidak efektif. Pada 12-14 Februari 2014 Yoyok mengadakan Pameran APBD di kantor Pemkab Batang di Jalan Veteran diikuti seluruh satuan kerja perangkat dinas (SKPD). Setiap stand menampilkan data, dokumentasi dan audio visual penggunaan PAGU anggaran dari masing-masing SKPD. Data yang ditampilkan bersifat rigit hingga pada sub rincian objek belanja. Pengunjung yang membawa laptop dapat mengakses database (soft copy) dari SKPD. Pameran diisi dengan diskusi dan seminar dengan nara sumber dari Komisi Pemberantasan Korupsi (KPK), Transparancy International Indonesia (TII), dan Indonesian Corruption Watch (ICW).

Kiprah expo budget 2014 ini mendasari lahirnya FA 2016 yang dikelompokkan dalam 4 bidang yakni bidang pengelolaan keuangan daerah, bidang pembangunan infrastruktur urusan 
wajib, bidang pelaksanaan pelayanan publik dan bidang penyelenggaraan pembangunan desa. Dimasukkannya dana desa dalam booth di FA ini dengan pertimbangan untuk mencegah penyelewengan dana desa yang mulai 2016 naik menjadi Rp 600 juta per desa oleh Kemendagri. Hal ini diakui Yoyok karena sepengetahuannya pengelolaan dana desa yang sangat besar itu ternyata belum dikerjakan dengan baik oleh para kepala desa.

FA 2016 dibiayai APBD Rp 381 juta yang merupakan DPA di Dinas Pendapatan, Pengelolaan Keuangan dan Aset Daerah (DPPKAD) ditambah dana dari CSR menjadi Rp 494 juta. Tenda pameran bersifat indoor dengan partisi yang melibatkan event organiser (EO). Sejumlah nara sumber yang terlibat Menteri Desa Pembangunan daerah Tertinggal dan Transmigrasi, Ombudsman RI, FITRA, TII, Kepala Perwakilan BPK Jawa Tengah dan Walikota Surabaya. Untuk menyemarakkan acara, panitia menampilkan hiburan dan pertunjukan seni wayang oleh $\mathrm{Ki}$ Entus Susmono yang juga Bupati Tegal.
Tabel. 1

Kondisi Festival Anggaran Batang 2016:

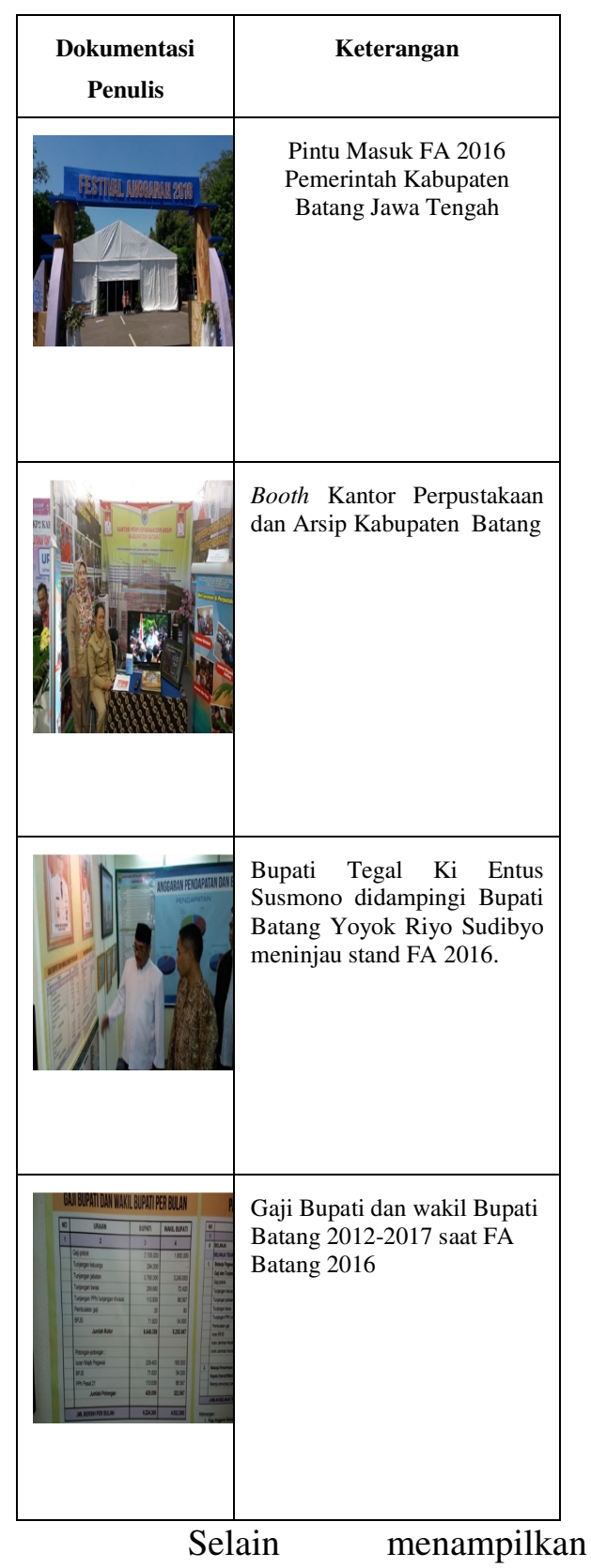

penggunaan APBD dan program pembangunan di masing-masing SKPD hingga ke tingkat desa, dalam festival tersebut juga memajang gaji bupati dan wakil bupati, ketua DPRD, wakil ketua DPRD dan anggota DPRD. 
Pengunjung mayoritas kaget melihat gaji bersih Bupati Batang Rp 6.224.300 dan gaji Wakil Bupati Batang Rp 4.932.500. Sedangkan gaji bersih Ketua DPRD Rp 6.168.590 dan anggota DPRD Rp 4.861.380. Juga memamerkan pagu anggaran tahun 2016 dengan jumlah belanja tidak langsung Rp 715.369.532.

\section{Analisis Kebijakan Komunikasi}

Secara keseluruhan muatan konteks, domain dan paradigma kebijakan komunikasi FA seperti yang diungkapkan Bupati Batang 2012-2017 Yoyok sebagai berikut:

"Pemerintah kini semakin berupaya mewujudkan good governance, salah satunya melalui transparansi informasi publik yang akurat dan memadai tentang pemerintah kepada publik untuk mencegah KKN. Berkaitan pengelolaan keuangan daerah, sesuai Permendagri Nomor 13 tahun 2006 pasal 4 menyebutkan bahwa keuangan daerah dikelola secara tertib, taat pada peraturan perundangundangan, efektif, efisien, ekonomis, transparan dan bertanggungjawab dengan memperlihatkan azas keadilan, kepatutan dan manfaat bagi masyarakat. Dalam UU No 14 tahun 2008 tentang Keterbukaan Informasi Publik, laporan keuangan sebagai salah satu informasi yang wajib diumumkan secara berkala oleh Badan Publik. Festival Anggaran sebagai bentuk laporan pertanggungjawaban uang rakyat kepada rakyat yang selayaknya bisa menjadi agenda rutin untuk memberantasKKN, penguatan ekonomi daerah dan masyarakat Batang yang sejahtera. Karena rakyat bisa secara langsung bertanya tentang penggunaan anggaran ataupun program pembangunan kepada aparat, memberi masukan ataupun komplain. Dengan cara ini mendorong rakyat untuk ikut peduli dalam proses pembangunan (Ibid, Yoyok Riyo Sudibyo).

Bertolak dari hasil wawancara di atas, konteks FA dikaitkan dengan kebijakan komunikasi yakni politik komunikasi, yang mengandung domain untuk mewujudkan tata pemerintahan yang bersih, akuntabel, transparans dan partisipatif. Serta paradigma terwujudnya masyarakat informasi dalam pemerintahan yang bebas KKN seiring Reformasi 1998.

Untuk lebih jelasnya, proses kebijakan komunikasi FA Batang dibuat dalam tabel: 
Tabel. 2

Proses Kebijakan Komunikasi FA Batang 2014-2016

\begin{tabular}{|c|c|c|c|c|}
\hline \multicolumn{5}{|c|}{ 2014-2016 } \\
\hline $\begin{array}{l}\text { Komun } \\
\text { ikator }\end{array}$ & Pesan & $\begin{array}{l}\text { Salura } \\
\text { n }\end{array}$ & $\begin{array}{l}\text { Komu } \\
\text { nikan }\end{array}$ & Efek \\
\hline $\begin{array}{l}\text { Bupati } \\
\text { Batang } \\
(2012- \\
2017) \\
\text { Yoyok } \\
\text { Riyo } \\
\text { Sudib } \\
\text { yo } \\
\text { Lokasi: } \\
\text { Pem } \\
\text { kab } \\
\text { Batang, } \\
\text { Jawa } \\
\text { Tengah }\end{array}$ & $\begin{array}{l}\text { 1.Trans } \\
\text { paransi } \\
\text { penggun } \\
\text { aan } \\
\text { APBD } \\
\text { secara } \\
\text { terbuka, } \\
\text { lang } \\
\text { sung } \\
\text { dan } \\
\text { dialogis } \\
2 . \\
\text { Menceg } \\
\text { ah } \\
\text { KKN. } \\
\text { 3. } \\
\text { Menduk } \\
\text { ung era } \\
\text { informa } \\
\text { si publik } \\
\text { sesuai } \\
\text { UU KIP } \\
\text { dan UU } \\
\text { tentang } \\
\text { good } \\
\text { gover } \\
\text { nance }\end{array}$ & $\begin{array}{l}\text { 1. FA } \\
\text { 2.Ra } \\
\text { pat } \\
\text { 3.Sosia } \\
\text { lisasi } \\
\text { 4.Dis } \\
\text { kusi } \\
\text { 5.Jump } \\
\text { a pers } \\
\text { 6.Ik } \\
\text { lan di } \\
\text { media } \\
\text { massa }\end{array}$ & $\begin{array}{l}\text { 1.PNS } \\
\text { Pem } \\
\text { kab } \\
\text { Batang } \\
\text { 2.DPR } \\
\text { D } \\
\text { 3.Insti } \\
\text { tusi } \\
\text { pemeri } \\
\text { ntah } \\
\text { 4.LSM } \\
\text { 5.Masy } \\
\text { ara } \\
\text { kat } \\
\text { 6.Pro } \\
\text { Fesio } \\
\text { nal }\end{array}$ & $\begin{array}{l}\text { 1.Mas } \\
\text { yarakat } \\
\text { mulai } \\
\text { kritis } \\
\text { terhada } \\
\text { p } \\
\text { pemban } \\
\text { gunan } \\
\text { yang } \\
\text { tidak } \\
\text { sesuai } \\
\text { yang } \\
\text { diumu } \\
\text { mkan. } \\
2 . \\
\text { Adopsi } \\
\text { kebijak } \\
\text { an oleh } \\
\text { pemerin } \\
\text { tah } \\
\text { daerah } \\
\text { dan } \\
\text { institu } \\
\text { si } \\
\text { pemerin } \\
\text { tah }\end{array}$ \\
\hline
\end{tabular}

1. Tahap penyusunan agenda menurut Subarsono (2005:11) dalam Abrar (2008:47) ada tiga kegiatan yang harus dilakukan yakni 1) membangun persepsi di kalangan stakeholders tentang persoalan yang harus diselesaikan, 2) membuat batasan masalah 3) memobilisasi dukungan agar suatu persoalan masuk dalam agenda pemerintah.

Bertolak dari FA, Yoyok menguraikan sebagai berikut:

"Sesuai janji saya kepada rakyat, maka setiap tahun saya akan melaporkan langsung hasil kerja saya kepada rakyat, selain laporan normatif ke
DPRD. Dengan cara ini saya ingin membangun partisipasi publik. Pelaksanaan Festival Anggaran juga dimaksudkan sebagai rangkaian peringatan HUT Kabupaten Batang pada Februari. Sejak Indonesia merdeka, baru Kabupaten Batang yang mengadakan kegiatan ini" (Ibid, Yoyok Riyo Sudibyo)

FA menjadi agenda yang dilakukan Pemkab Batang sebagai realisasi ide dari Bupati Yoyok, sekaligus merupakan bagian dari rangkaian peringatan HUT Kabupaten Batang. Yoyok berupaya menjalankan tata kelola pemerintahan yang akuntabel, transparan dan partisipasi publik. Terlebih didasari dari pengalaman bupati sebelumnya yang terjerat kasus korupsi APBD dan semakin merebaknya budaya koruptif di kalangan kepala daerah seiring pasca reformasi.

\section{Tahap formulasi kebijakan}

komunikasi: Kiprah Yoyok melalui kebijakan FA bertujuan membuka akses informasi publik akan tata kelola APBD agar diketahui publik dalam mendukung era masyarakat informasi. Jones (1996;47) dalam Tahir (2014:25) berpendapat kebijakan merupakan keputusan tetap yang dicirikan oleh 
konsistensi dan pengulangan tingkah laku dari mereka yang membuat dan dari mereka yang mematuhi kebijakan tersebut.

Asisten I Sekda Batang, Retno Dwi Irianto kepada peneliti menjelaskan untuk menyukseskan FA Batang 2016, Bupati Batang Yoyok membentuk tim kepanitiaan melalui Surat Keputusan (SK) Bupati. Adapun untuk pelaksanaan FA Batang khususnya 2014 dan 2016, Bupati Yoyok tidak menerbitkan SK Bupati, ataupun Peraturan Bupati maupun Peraturan Daerah (Perda). Namun merupakan penjabaran pelaksanaan program kegiatan di masing-masing SKPD dan UKPD yang menginduk pada program bupati sesuai dalam

Rencana Pembangunan Jangka Menengah Daerah (RPJMD) 2012-2017.

Berikut wawancara peneliti dengan Retno Dwi Irianto:

"Untuk pelaksanaan Festival Anggaran Batang 2016 secara spesifik tidak ada SK Bupati, Peraturan Bupati ataupun Perda. Karena pada dasarnya hal ini merupakan pelaksanaan program kerja. Dikaitkan Festival Anggaran 2016 dahulu masuk dalam Dinas Pengelolaan Pendapatan Keuangan dan Aset Daerah (DPPKAD) yang kini berganti menjadi Badan Pengelolaan Keuangan dan Aset Daerah (BPKAD). Anggaran tersebut untuk membiayai tempat dan infrastruktur pendukung" (Sumber: hasil wawancara peneliti dengan Asisten I Sekda Batang pada 3 Oktober 2017).

\section{Reaksi positif maupun}

apresiasi akan FA Batang juga berdatangan mulai kalangan birokrat, KPK, Ombudsman hingga LSM anti korupsi seperti FITRA, TII, dan ICW. Deputi Menteri Pemberdayaan Aparatur Negara dan Reformasi Birokrasi (PAN RB) Bidang Pelayanan Publik, Mirawati Sudjono mengapresiasi FA Batang yang merupakan inovasi pelayananan publik dan daerah lain dapat belajar ke Batang. Sehingga tepat dilombakan dalam kompetisi inovasi pelayanan publik. Bahkan inovasi tersebut dinilai sukses memosisikan rakyat hingga lapisan terbawah memiliki pengawasan yang kuat terhadap APBD.

(https://news.detik.com/berita/316 3670/festival-anggaran-pemkabbatang-tuai-apresiasi-daerah-laindiminta-meniru). 


\begin{tabular}{lrr}
\multicolumn{2}{c}{ FA } & \multicolumn{2}{c}{ Batang } & menurut \\
Sekjen & TII, Dadang & Tri \\
Sasangoko & dapat & menjadi \\
kebijakan & pemerintah & pusat \\
sehingga & masyarakat & dapat \\
mengetahui & apapun & alokasi \\
anggaran yang digulirkan. Konsep \\
Festival Anggaran ini & dapat \\
dilakukan & daerah & lainnya \\
disesuaikan & dengan & kebutuhan \\
masing-masing. & \\
(http://www.tribunnews.com/nasi \\
onal/2016/03/06/langkah-bupati- \\
batang-selenggarakan-festival- \\
anggaran-bisa-jadi-kebijakan- \\
nasional)
\end{tabular}

\section{Tahap adopsi kebijakan;}

Bupati Yoyok mengklaim pelaksanaan buka-bukaan anggaran tersebut mendapat dukungan dari kalangan legislatif, selain dari masyarakat, birokrat, profesional dan LSM anti korupsi seperti FITRA, ICW dan TII. Serta diapresiasi oleh KPK, Ombudsman, BPK dan Festival Anggaran Batang 2014 Yoyok mendapat penghargaan Bung Hatta Awards terkait tata kelola pemerintahan yang transparan.

Pada FA 2016 dilakukan dengan menyempurnakan FA 2014 dan tidak lagi dilakukan dengan menyebarkan brosur, selebaran, ataupun mengundang sosialisasi RT-RW, dan perangkat desa hingga camat.

Hal ini seperti dikatakan Kabag Organisasi Setda Batang, Retno Dwi Irianto yang juga sebagai Wakil Ketua IV dalam susunan keanggotaan tim FA 2016:

"Gagasan pak bupati untuk penyelenggaran Festival Anggaran 2016 tetap mengacu pada Festival Anggaran 2014 namun lebih terarah dan lebih fokus. Pada Festival Anggaran 2014 mulai menggunakan event organizer namun belum sistematis. Pada Festival Anggaran 2016, kami tetap menggunakan event organizer sesuai aturan dengan biaya APBD dan sebagian dari pihak swasta melalui dana CSR. Dalam Festival Anggaran 2016, kami menampilkan kegiatan pembangunan 2014 dan 2015 serta rencana pembangunan yang sudah ditetapkan pada 2016 yang menampung masukan atau aspirasi masyarakat.", (Sumber: hasil wawancara peneliti pada 16 Maret 2016)

\section{Tahap implementasi}

\section{kebijakan;}

Pada FA 2016, kegiatan difokuskan dalam 4 bidang seperti yang dijelaskan Ketua Panitia FA Batang 2016 yang juga Setda Batang, Nasikhin: 
"Festival Anggaran 2016 fokus pada 4 komponen yakni bidang pengelolaan keuangan daerah, bidang pembangunan infrastruktur urusan wajib/pelayanan dasar, bidang pelaksanaan pelayanan publik dan bidang penyelenggaraan pembangunan desa. Jadi pengelompokkannya tidak menurut jumlah SKPD. Tenda pameran indoor dengan partisi, anggaran APBD sebesar Rp381 juta yang berasal dari DPA Dinas Pendapatan Pengelolaan Keuangan dan Aset Daerah (DPPKAD) Kabupaten Batang. Selama 3 hari diisi dengan serangkaian acara seperti seminar nasional dan diskusi publik serta hiburan dan wayang. Hal yang menjadi primadona karena pengunjung bisa melihat sendiri gaji bupati dan wakil bupati serta Ketua DPRD dan Wakil Ketua DPRD selain pengelolaan APBD sesuai 4 komponen dari masing-masing stand." (Sumber: hasil wawancara peneliti pada 16 Maret 2016)

\section{Tahap evaluasi kebijakan;}

Evaluasi merupakan kegiatan yang menganalisis dan menyajikan informasi yang bermanfaat tentang objek evaluasi, menilainya dengan membandingkandengan indikator evaluasi dan hasilnya digunakan untuk mengambil keputusan mengenai objek evaluasi (Wirawan,2012:7). Evaluasi sebagai proses yang bertujuan memastikan tindakan strategik sudah sesuai atau tidak dengan rancangan awal atau perumusan strategik yang ditetapkan.

Koordinasi dari tim panitia yang tidak kompak sehingga FA 2016 berlangsung tidak sesuai dengan target awal yakni pada Februari, tapi diadakan selama 3 hari sejak 13 Maret 2016.

Bertolak dari penjelasan di atas, model komunikasi FA

Batang sebagai berikut:

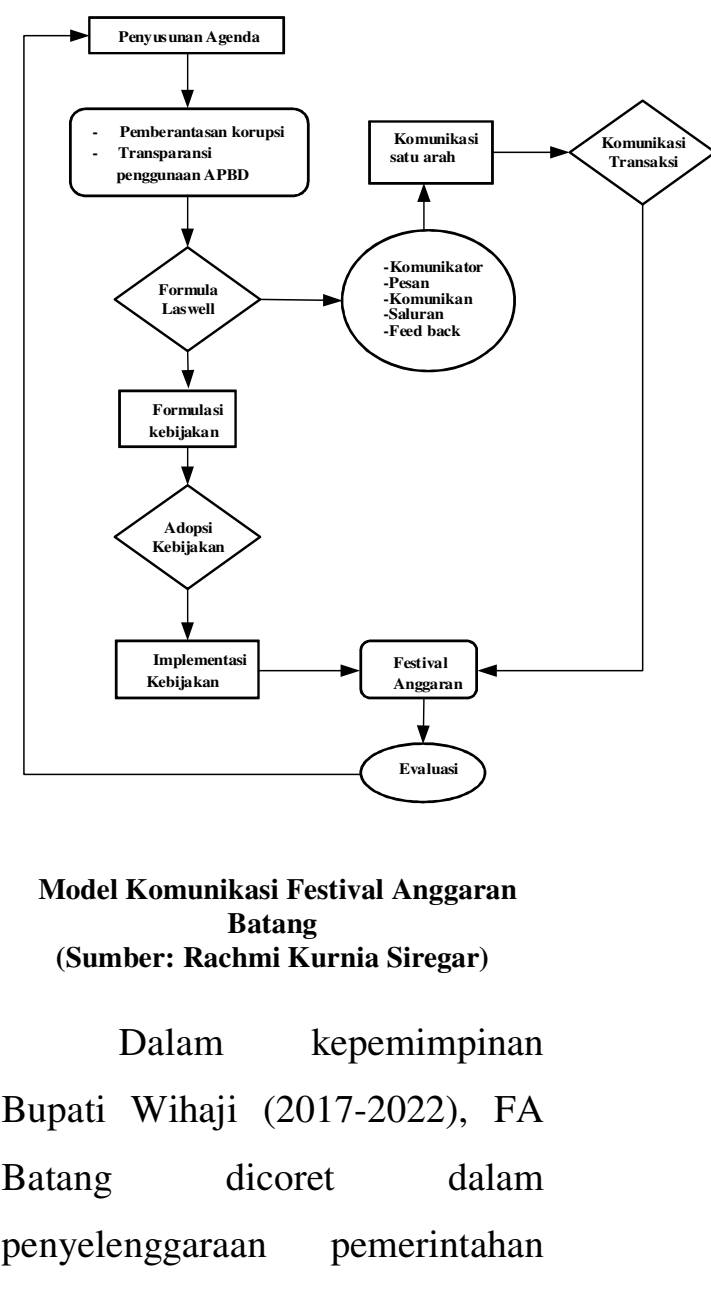

penyelenggaraan pemerintahan 
bidang e-government meliputi $e$ planning, e-budgeting, SIMDA Keu (Sistem Informasi Manajemen Daerah), $e$ procurement, Simpelbang (Sistem Informasi Monitoring

Pengendalian dan Evaluasi

Pelaporan Pembangunan), Simda

Barang (Sistem Informasi

Manajemen Daerah) Barang Milik

Daerah, e-Sakip (Ssitem

Akuntabilitas Kinerja Instansi

Pemerintah) dan lainnya. Serta

mempertahankan PPID (Pejabat

Pengelola Informasi dan

Dokumentasi (PPID) sesuai

amanat UU No 14 tahun 2008

tentang Keterbukaan Informasi

Publik dan UPKP yang merupakan lembaga adhoc bentukan Yoyok sebagai sarana pengaduan masyarakat bertujuan menyelesaikan masalah seraya mengawasi pelayanan publik di jajaran Pemkab Batang.
Pada hakekatnya kebijakan

e-Government ini dirintis Yoyok meski dalam masih format sederhana. Sehingga awal 2017 program tersebut disempurnakan dan diperkuat dengan Smart City yang dapat diakses melalui website Pemkab Batang (https://batangkab.go.id/).

Berikut penyelenggaraan pemerintahan Bupati Wihaji-

Suyono dalam hal e-Government:

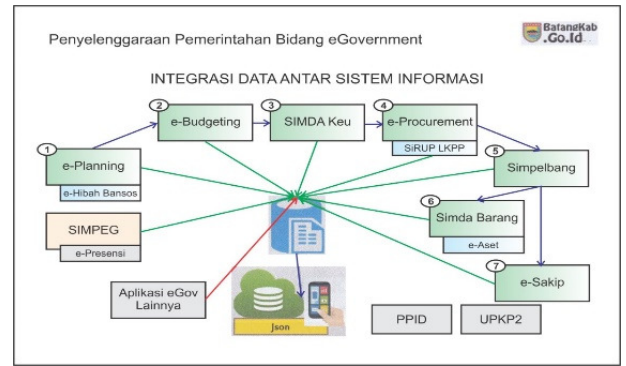

Penyelenggaraan pemerintahan bidang e-Government Bupati Wihaji

\section{SIMPULAN}

Kebijakan FA berasal dari ide dasar Yoyok selaku kepala daerah untuk membuka akses kepada publik terkait transparansi pengelolaan APBD. Semula komunikasi organisasi FA cenderung satu arah, namun berkembang menjadi komunikasi transaksi setelah Yoyok menjalin jaringan dengan berbagai pihak yang berkompeten di antaranya Ombudsman, KPK, LSM anti korupsi seperti ICW, FITRA dan 
TII. Kebijakan komunikasi FA merupakan kebijakan politis dari Yoyok selaku komunikator dalam menyampaikan pesan kepada jajarannya terkait transparansi untuk memberantas KKN. Pesan tersebut dalam rangkaian komunikasi politik yang bertujuan masyarakat menjadi kritis terhadap tata kelola anggaran daerah dan pembangunan. FA Batang diadopsi pemerintah daerah yakni Pemkab Karanganyar pada 2016 dan 2017 yang memamerkan anggaran tahun berjalan, di tingkat nasional inovasi Yoyok ini menginspirasi Direktorat Jenderal Anggaran Kementerian Keuangan dengan menggelar Open Portal Data APBN pada Oktober 2017. Proses pembuatan kebijakan komunikasi FA sesuai Dunn (2003) diawali dari penyusunan agenda yang mengusung tema transparansi dan memberantas KKN, formula kebijakan ditandai dengan tidak adanya aturan khusus (regulasi) akan FA namun kegiatannya menginduk sesuai RPJMD 20122017, adopsi kebijakan dengan adanya dukungan dari KPK, Ombudsman dan LSM anti korupsi. FA Batang 2016 berlangsung 3 hari pada 13 Maret 2016 dan dievaluasi sebagai bahan kajian pemkab setempat.

Penerapan kebijakan komunikasi FA Batang 2017 terkendala dengan berakhirnya masa tugas Yoyok. Dipimpin Bupati Wihaji (2017-2022) yang dilantik pada Mei 2017, mencoret FA dalam penyelenggaraan pemerintahannya. Namun Wihaji tetap berkomitmen menjalankan transparansi anggaran serta membuka akses bagi publik melalui pelayanan e-Government dan smart city.

\section{Ucapan Terima Kasih}

- Kementerian Riset Teknologi dan Pendidikan Tinggi Republik Indonesia, Direktorat Jenderal Penguatan Riset, Teknologi dan Pendidikan Tinggi Republik Indonesia.

- Rektor Universitas Budi Luhur Prof. Dr. Sc. Agr. Ir. Didik Sulisytanto.

- Dekan Fakultas Ilmu Komunikasi Rocky Prasetyo Jati, Msi

- Direktur Riset dan Pengabdian kepada Masyarakat Prof. Dr. FX. Suwarto, M.S

- Berbagai pihak yang membantu pelaksanaan penelitian ini.

DAFTAR PUSTAKA 
Buku:

Abrar, Ana Nadhya (2008). Kebijakan Komunikasi: Konsep, Hakekat dan Praktek. Gava Media, Yogyakarta.

Afdjani, Hadiono (2014). Ilmu Komunikasi, Proses dan Strategi. Universitas Budi Luhur dan Indigo Media, Jakarta.

Brent D. Ruben \& Lea P. Stewart. Communication and Human Behavior (fifth edition). Rajagrafindo Persada., Jakarta.

Dunn, William (2003). Pengantar Analisis Kebijakan Publik. Edisi Kedua, disunting oleh Muhadjir Darwin. Gadjah Mada University Press, Jakarta.

Mulyana, Dedy (2008). Ilmu Komunikasi Suatu

Pengantar. Remaja

Rosdakarya, Bandung.

Romli, Khomsahrial (2014). Komunikasi Organisasi Lengkap. Grasindo, Jakarta. Alfabeta, Bandung.

Tahir, Arifin (2014), Kebijakan Publik \& Transparansi Penyelenggaraan Pemerintah Daerah. Alfabeta, Bandung.

Tubss, L.Stewart, Moss Silvia (2005). Human Communication. Remaja Rosdakarya, Bandung.

Jurnal:

Aritonang, Agusly Irawan (2011).

Kebijakan Komunikasi di Indonesia: Gambaran Implementasi UU No. 14 tahun 2008 tentang Keterbukaan Informasi Publik, Jurnal Komunikasi, Volume 1, Nomor 3, Juli. (diakses pada 15 Agustus 2016)
Rosfiantika, Evi dan Rodaih, Saleha (2015). Strategi Komunikasi Kebijakan Perlindungan dan Pengelolaan Sumber Daya Alam dan Lingkungan Hidup Berdasarkan Kearifan Lokal di Kabupaten Tasikmalaya. Universitas Padjajaran, Bandung. (diakses pada 14 Agustus 2016)

\section{Disertasi:}

Julianti (2015). Formulasi Strategi Komunikasi Kebijakan Kehutanan: Kasus Pembangunan Kesatuan Pengelolaan Hutan. Institut Pertanian Bogor.

\section{Tesis:}

Andrianto, Muhammad (2012). Evaluasi Penyusunan Anggaran dan Alokasi Anggaran Belanja Daerah: Studi Kasus Pada Pemerintah Daerah Kabupaten Karanganyar. Universitas Sebelas Maret. Surakarta.

Indriasari , Sonia (2009). Pengelolaan Festival Budaya di Indonesia. Studi Kasus: Pengelolaan Festival Tradisi Lisan Maritim Wakatobi.

\section{Skripsi:}

Saputro, Johan (2014). Perencanaan Event Management Festival Kesenian

$\begin{array}{lr}\text { Yogyakarta } & \text { Sebagai } \\ \text { Media } & \text { Komunikasi } \\ \text { Identitas } & \text { Yogyakarta. } \\ \text { Universitas } & \\ \text { Islam Negeri Sunan } & \text { Salijaga, Yogyakarta. }\end{array}$

Website:

Paskah Suzeta, Paparan Menteri 
Perencanaan Pembangunan Nasional/Badan

Perencanaan Pembangunan Nasional Pada Rapat Koordinasi Nasional Departemen Komunikasi dan Informatika 2006 di Jakarta, 19 September 2006.

http://www.antikorupsi.org/en/no de/56203 diunduh pada Minggu (24April2016).

http://kbbi.web.id/transparansi http://batangkab.go.id/?page_id=1 42

Harjana, Andre dalam Buku Audit Komunikasi, Teori dan Praktek (http://www.kamusbesar.com/640 03/kebijakankebijakankomunikasi)

http://www.anggaran.depkeu.go.i d/dja/edef-konten-

view.asp?id=1262 (diakses pada 13 September 2017 pkl: 15.30) 